\title{
Persuasive Power Concerning COVID-19 Employed by Premier Imran Khan: A Socio- Political Discourse Analysis
}

\section{Zafar Iqbal ${ }^{1}$, Muhammad Zammad Aslam², Talha Aslam³ $^{3}$} Rehana Ashraf ${ }^{4}$, Muhammad Kashif ${ }^{5}$, Hafiz Nasir ${ }^{6}$

Department of English, Minhaj University, Lahore, Pakistan ${ }^{1}$, Universiti Utara Malaysia ${ }^{2}$, Bahria Business School, Bahria University, Islamabad, Pakistan ${ }^{3}$, M.Phil Scholar, NCBA\&E, Multan, Pakistan ${ }^{456}$

E-mail: zafar.iqbal.publishing@gmail.com¹, zammad.aslam@gmail.com², talha.aslam387@gmail.com ${ }^{3}$

${ }^{*}$ Corresponding Author

DOI: https://doi.org/10.18326/rgt.v13i1.208-230

\section{Submission Track:}

Received: $12-05-2020$

Final Revision: 29-05-2020

Available online: $01-06-2020$

\begin{abstract}
The researchers investigate Pakistani Premier Imran Khan's (IK) addresses to the nation concerning awareness about the causes, effects, precautions, and
\end{abstract}


solutions of the Novel Corona Virus (COVID-19). Till the date, experts are not sure whether the vaccine will get developed or would we have to live with this as we did with HIV or Dengue. Consequently, leaders would need to address their nations, focusing specifically on precautions. The present research employs Aristotle's persuasive and rhetorical devices, integrating them with Socio-Political Discourse Analysis (SPDA), to understand the social and political convincing style employed by the premiere. The researchers analyzed the data employing a qualitative approach. There are reliable findings to suggest that IK has used stable linguistic features to persuade the minds of the people, convincing them to follow the precautionary measures as the only cure.' The defending arguments about semi-lockdown or smart-lockdown were well-defined persuading the individuals; for instance, he suggested the smartlockdown during his first address and faced criticism from the opposition. Later, the opposition and the world appreciated the policy of IK, the Premier of Pakistan, even being a developing country in the sight of the world. After one month of the first patient of the corona case reported in China, the policy of smart-lockdown was followed by most of the states fighting against COVID19. Moreover, The Premier successfully persuaded the international financial organizations - IMF, World Bank, Development Banks, convincing them to waive off the pending payments of developing countries for the upcoming year.

Keywords: COVID19, Persuasion, Socio-Political Discourse Analysis, Speeches, Linguistic Features

\section{INTRODUCTION}

The research depicts the socio-political discourse analysis of the speeches of Premier Imran Khan (IK) with the perspective that he uses persuasive strategies (Ethos, Logos, Pathos, and some other strategies of persuasion; see Sibtain et al., 2020 for details) to create the awareness related to the consequences and precautions of Novel COVID-19. Political speech is a persuasive longstanding political genre (Latif, 2016). Speech discourse is the most known type of composed talk, which is broadly practiced by individuals, 
which can also be referred to as the most precise type of written content. SPDA is a tool that helps the researchers and audience to understand the implicit meanings in the composed text or speech in the context of social and political scenarios.

The COVID-19 retains various signs like fever, pneumonia, lung infection, cough, flu, and respiratory issues (Hani et al., 2020; WMHC, 2020). Even though coronavirus was commonly found in animals around the world but rare cases in humans until December of 2019. WHO (World Health Organization) named this term COVID-19, which is an abbreviation of Co 'Corona', Vi 'virus,' D, 'December,' and 19 '2019'. In December 2019, it affected the lower breathing tract of the patients by pneumonia in the city of Wuhan, China (Li et al., 2020; WHO, 2020). After the reporting of a few cases, this virus spread immediately and quickly, within one month (January 31, 2020 - February 29, 2020), the cases were reported in thousands; more than three thousand died in China alone (WHO, 2020a).

Most of the medical experts claim COVID-19 as a type of flu, but it is more harmful than the conventional flu and spreads from one person to another through physical contact, nasal exhales (cough \& sneeze) and point of contacts like, handshakes, mutual contact of surfaces, and hugs (WHO, 2020b). WHO (2020b) recommended some precautions to avoid it because the vaccination is always the last resort in viral diseases since they take months and years to get developed and tested, meanwhile, only the safety precautions can keep us safe from the disease. We can avoid it by using an effective face mask, wearing gloves, washing hands as per the expert guidelines (before and after performing 
any human social activity), using hand sanitizer, self-isolation, and avoiding crowds.

The researchers reviewed the topic related literature with extensive reading of the published articles. They observed that political leaders consciously/intentionally utilize various language skills to persuade masses and stakeholders to impose ideologies locally and internationally (Norali \& Rezaei, 2016). Therefore, the researchers analyze the speeches of IK that are concerned with the novel COVID-19. Imran Khan, Premier of Pakistan, has profound language and persuasive skills that affect the mind of the listeners, and listeners happily accept his ideology (Sibtain et al., 2020).

Coronavirus was firstly found in December 2019 in Wuhan, China. Therefore, the scientists and researchers instantly started to find the sources and symptoms of the novel COVID 19, and Prof. Yong-Zhen Zhang and his team published his first article on COVID-19 in January 2020 (WHO, 2020). Moreover, they claimed that the virus spread very quickly in China within one month, primarily due to New Year because it is the period when a high level of human mobility can be found among the people of China (Wu et al., 2020). Nevertheless, it is too early to expect susceptible populations because now, it has spread at a large scale throughout the world. China, even being the origin, has controlled it at the maximum capacity, but still, it could return at any point in time as it is still out there in the world. Within four months, it has reached more than 216 countries, territories, or areas (WHO, 2020).

The vaccine for the cure of the virus is under development stages, and, till the date, it does come out in the final shape, the earth is endangered. The fundamental source of the spread of COVID-19 is gathering and traveling of 
individuals, as an affected person can affect many others whom he or she meets or fulfills any of the conditions mentioned earlier of physical contact. However, many countries, including China and Pakistan, locked-down the whole countries, some did it at very early stages, and some took their fair amount of time for the decision. Till the date, more than 5.2 million people have been affected, and more than 337736 people have died (WHO, 2020, May 25). However, the number of increasing cases of confirmed corona affected patients has not stopped yet.

Henceforth, the researchers aim to highlight and discuss the role played by Pakistani Premier Imran Khan through his speeches, creating awareness about the precautions as well as taking the people in confidence by explaining his Cabinet's steps and role to keep the people of the nation safe.

\section{Theoretical contribution}

Sibtain et al. (2020) employed Aristotle's Rhetorical Devices on the speeches of IK; and concluded that the leaders consciously employ them applicably to persuade the minds of the people through media (print, social and electronic media). The researchers of the present study also extracted the speeches/addresses of IK for analysis collecting the data from electronic media, which availed in video form from YouTube. The researchers also engaged rhetorical devices employed in speeches to impose ideology(ies) on the minds of the people locally and internationally. For instance, there is no protest raised against the steps taken by the Pakistani government concerning COVID-19. Additionally, international leaders and organizations (precisely WHO) also 
appreciated and granted aid to the developing countries that IK requested from international organizations (WHO, IMF, World Bank).

The study participates in the field of linguistic persuasion employing rhetorical devices - Ethos; through this device, the speakers use the ethical language based on morality to attract the attention of individuals (audience/spectators). Secondly, they use the rhetorical device 'Logos' to prove the ideology correct and authentic through logic. Lastly, they use the device 'Pathos' to evoke the emotions of spectators through the speeches, and the individuals agree to the voice of orator (Higgin \& Walker, 2012; Ting, 2018; Sibtain et al., 2020).

\section{Socio-Political Discourse Analysis}

Political Discourse is an essential perspective that helps to build implicit and explicit meanings in the targeted text, specifically in a social and political context (van Dijk, 2018; 2006; 2005; 1997b; 1998). Although it narrates social practices, power relations, and abstract considerations, additionally, it is an approach to communicate, through words, in speech (discourse) or composed structure (written form). A Language that is utilized with the end goal of correspondence with other people by writing a text or using speech sounds to communicate is called discourse (Sharififar \& Rahimi, 2015). Discourse can be investigated in various ways with various goals by setting, translation, and depiction yet additionally clarification of how and why it functions (Rogers \& Schaenen, 2014). Discourse is a part of the language with a practical approach and deals with every kind of person's intellect. In contrast, discourse analysis is an objective type of technique structure that considers the content of discourse or any kind of framework which deals with 
any method of communication to study text in context (Sibtain et al., 2020; Sharififar \& Rahimi, 2015).

Kirvalidze \& Samnidze (2016) argue that political discourse could be divided into; the political context, social ideology, psychological effects, and the individual's perception that can be exposed through political discourse analysis. The text can be broken down into three indivisible parts, i.e., language, interaction, and communication (van Dijk, 1997b). Further, in the contemporary era, political discourse analysis is an interdisciplinary methodology functioning at macro and micro-scale levels - incorporated at the linguistic and social levels. Political Discourse Analysis is based on occasions at an educational level, which comprehends specific convictions, personalities, legislative (political) issues, philosophies, and some other things identified with it (Wodak, 2011; Dunmire, 2012; Kervalidze \& Samnidize, 2016)

Moreover, according to Kirvalidze \& Samnidze (2016), Political Discourse Analysis can be combined with various type of analyses like psychological sciences that appraises philosophy. That is the reason it turned into the most generally utilized technique in the field of present-day linguistics. It additionally uncovers the belief systems and power relations mostly in political discourse. Moreover, PDA is a blend of speculations identified with smaller-scale human science, society, and power (van Dijk, 2001; Kirvalidze \& Samnidze, 2016; Sibtain et al., 2020). It is a comprehensive method and technique for clarifying while investigating the discourse. A few critics state that there is not a specific method existing for PDA or gathering information through PDA. Instead, it is a crude material for dissecting and analyzing 
content inside a unique setting. The essential job of PDA is to uncover the connection of language, philosophical values, power, society, and other perspectives. Xie (2018) suggests that PDA is a tool to conduct speech discourse that turned out to be progressively well known and get more thoughtfulness regarding the individuals. In the contemporary era, conducting discourse study in English speeches is exceptionally become mainstream since the English language has a significant effect at the universal level. Hence, political individuals, through speeches or debates, influence and persuade others, keeping compelling arguments to get the emotional and political support (Fischer \& Gottweis, 2012).

Sarfo \& Krampa (2013) argue that we could interpret the implicit meanings using persuasive and linguistic devices, especially in a social context. Speeches have also received considerable attention from scholars, researchers, and linguists. These studies mostly highlighted issues of racism, identity, cultural transmission, and other prominent political issues. Apart from that, while some of the studies were conducted at pragmatic, semantic, stylistic, and lexicon-grammatical levels.

However, the researchers of the present study analyze the spoken text employing SPDA accompanied by persuasive and linguistic strategies employed by IK in his addresses to nation from March 17- March 30, 2020, examining the text according to its quality and social acceptance. For instance, Hassan (2018) claims that qualitative investigation, employing the conceptual frameworks of CDA, enables the researchers and spectators to know the hidden meaning of the text primarily through its relationship with social and political context. 


\section{Research gap and novelty}

The significance of the present examination lies in its noteworthy investigation and analysis of spoken discourse that plays a significant role in the field of applied linguistics, especially in Discourse Analysis. The study additionally adds various aspects to the field of Political Discourse Analysis by uncovering the job of political instruments in the development of spoken discourse inside specific settings/contexts that also help the reader to understand the socio-political ideology that lies in the speeches delivered by the politicians. Besides, the examination endeavor will likewise help normal pursuers in scrutinizing the discourse of media that are emotionally controlled by various on-screen characters to propel their political advantages. So, it additionally makes the explorers ready for additional exploration to be led on media discourse by utilizing distinctive theoretical frameworks. Right now, the flow of inquiry is exceptionally critical in its point and examination as it uncovered the concealed motivation of spoken media discourse.

The researchers aim to find persuasive strategies in IK speeches related to coronavirus. Moreover, the researchers analyze the data with the perspective of political discourse analysis by employing van Dijk's Political Discourse model (1997b). However, there has been little work done on IK speeches related to COVID-19, especially with the perspective of SPDA. Moreover, the researchers find the Aristotelian persuasive strategies in the Premier's speeches that make the speeches more effective. Hence, the problem, as mentioned earlier, has not been discussed by researchers, and yet it needs to be solved. So, the following points are going to be discussed objectively: 
- The research would bring out the persuasive strategies employed by IK in his speeches to impose his ideology on the mind of the people.

- The researchers explore that Political Discourse helps the researchers to find out the hidden agenda through social and political context.

\section{RESEARCH METHOD}

The researchers have analyzed the text with a qualitative method and an analytical approach. In this study, the researchers collected the data through random but purposive sampling technique from the speeches of Imran Khan related to the novel coronavirus. Moreover, the data is collected from the video speeches available on YouTube. The researchers have used the tools to interpret the targeted text: Rhetorical and persuasive devices have been employed by the researchers as the tools and model to interpret the data adapted and followed the models of Higgin \& Walker, 2012; Ting, 2018; and Sibtain et al., 2020. All the prior mentioned researchers analyzed the data employing these devices and sub-devices.

\section{A conceptual framework of the research}

The researchers adapted and modified the term Socio-Political Discourse Analysis specifically from Sibtain et al. (2020), which they utilized 
for investigation of mesmerizing features and rhetorical devices. Moreover, through which, they analyzed the political speeches of IK (PM of Pakistan) in the socio-political scenario. So, the researchers merged the PDA model of van Djik (1997b) with general Political Discourses analyzed by (Sibtain et al., 2020; Sharif, 2015; Renkema, as cited in Nordquist, 2017).

van Dijk (1997b) argues that "without collapsing political discourse analysis into critical discourse analysis, we would like to retain both aspects of the ambiguous designation: PDA is, both, about political discourse, and it is also a critical enterprise. In the spirit of contemporary approaches in CDA, this would mean that critical-political discourse analysis deals especially with the reproduction of political power, power abuse, or domination through political discourse, including the various forms of resistance or counter-power against such forms of discursive dominance" (p. 11). Fairclough \& Fairclough (2012) \& van Dijk (1993b) have stated that political discourse analysis deals with the consequences of political \& social inequality and discursive conditions that result from such domination (van Dijk, 1997b, p. 11). Furthermore, the language used in political speeches cannot be understood only by its literal meanings because mostly the politicians use the rhetorical and figurative language that could be understood only through social and political discourse.

\section{RESULTS \& DISCUSSION}

According to Wang (2010), CDA is mostly applied to socio-political discourse, including visual, written, and spoken texts that consider language as a cultural and social practice. However, the purpose of the present research is 
to describe the discourse of IK's addresses related to the creation of awareness about the pandemic of coronavirus. Moreover, IK possesses strong language skills that can impose his viewpoint on the minds of viewers and listeners (Shah \& Noreen, 2018).

In this section, the researchers analyze Premier Imran Khan's addresses/speeches with the theme that IK persuades the minds of people with his persuasive language and practical spoken skills. He imprints his sociopolitical ideology and impacts opinion formation. This article is related to $\mathrm{Mr}$. Khan's ideological strategy to win the confidence of people relevant to the consequences of the Novel COVID-19.

\section{Persuasive strategies}

According to Sibtain et al. (2020), there are following Aristotelian persuasive Strategies that can be found in Imran Khan's speeches:

\section{a) Ethos}

The meaning of Ethos is to persuade people with ethics by using the language based on religion or mortality. Such as most of the people, and the politicians in Pakistan, belong to Islam religion, and before starting their activities, they mostly offer some holy words from the Holy Quran like the verse بِِِّ اللهِ الرَّحمنِ الرَّحِيمِ (In the name of Allah Almighty, who is the most beneficent, the most merciful). The researchers' term this as the 'Holy Commencement Spell' for any ordinary or specific good deed. In addition to this, Imran Khan also adds a few religious words from the Holy Quran following the Commencement Spell; إِيَّالكَ نَعْبُدُ وإِيَّالكَ نَسْنَعِينُ (Verse 05, Surah Fatihah, AlQuran) (Trans. Thee (alone) we worship; Thee (alone) we ask for 
help) in the starting of every speech/address. According to Asgha (2017), IK always starts his speech according to the religious and societal norms and cultural relevance and ethics that people like and pay attention to.

In his first address to the nation on March 17, 2020, IK being the Premier of Pakistan, has addressed the nation about the effects of the novel COVID-19 on the world with the perspective of the awareness about the symptoms, causes, effects, safety precautions and steps that the government has taken to keep the nation safe from this disease (Khan, 2020, March 17). IK has strong language skills and can quickly get the confidence of the people, such as persuasive strategies are familiar in all speeches that persuade the mind of the people towards specific purposes. The people mostly accept his ideology (Sibtain, 2020), such as, in his $22^{\text {nd }}$ March's address, he starts his speech with the possessive pronoun "My Pakistanis" that affects the mind of the people because this pronoun shows his love with the nation, as he would consider the whole nation his family. Moreover, he makes the nation realize that he has no discrimination against anyone on the social and political level and being the Premier of Pakistan; he considers the whole nation equal in his eyes. For instance, Vulchanova et al. (2019) argue that language power can change the perception of the people, and IK has that power, and due to his persuasive skills of language, he attracts the attention of the people and imposes his ideology on their mind. Importantly, he starts the speech with the words that the people of his country want to listen to; then he comes to the point in his speech where the people feel fascinated and captivated. For instance, Mere Pakistanio ... aaik 
bari behas chali hoi hy... puray lockdown ka matlab mulk main curfew... logon ko ghron main band kr diya jaye... (Khan, 2020, March 22).

In the text, as mentioned earlier, Khan gives the reason why he comes here to bring his nation in confidence and why he is not in favor of lockdown in the country. So, Khan uses all the words within the social context to make the people understand why he has come on TV to address; then, he elaborates on the problems in detail. Such as, according to Martin \& Nakayama (2010), "discourse is the language in use, and it means that all the discourse is social. Besides, the language used, the words and meanings that are communicated it all depends not only on the context but also on the social relations that are part of that interaction (p. 233).

Further, Khan describes the social and ethical barriers that do not allow the government to lockdown the country. For example, Khan says that twentyfive percent (25\%) people of Pakistan living below the line of poverty, and the government cannot provide them food at home (Khan, 2020, March 22). In the above-discussed statement, Khan has given the reason why the government is not in favor of locking down the country entirely. So, we could support the comments with the words of van Dijk (1997b) that if we want to make translucent to the ideological opposition in political discourse, then it becomes necessary to explain the discourse by examining the context of the discourse as political \& social background of the conflict, historical and its main participants (van Dijk, 1998b, p. 61-63).

Moreover, Premier Imran Khan treats the nation as if the nation deserves the right to know all these details. He is making sure to make the people realize their right to information by continually referring to the 
prosperous countries of the world and their implied strategies. It is yet another persuasive technique where he directly compares his plans and strategies with the best of the world and proves his points through international validation in the best manner possible.

\section{b) Logos}

Logos is the second persuasive strategy that emphasizes logical appeal. The logical explanations in the addresses of the Premier are very well formulated and backed with reason. He logically compares his strategies with the best from across the world and provides a distinctive explanation to whatever he has implemented. He has a specific style of stressing on numbers, measurable facts, reliable information, and points of relevance.

As in his March 22, 2020, address, he also gives some logic to prove his ideology, as well as Sibtain et al. (2020), claims that we could find Aristotelian's second persuasive strategy (Logos) in IK speeches. So, the researchers argue that IK, throughout his speeches, gives reasons why he calls the nation for an address. For instance, in his second address, he says that "he 'comes' to address the nation to clarify that he has not proclaimed the full lockdown in the country, because the government could not afford to feed the nation and needy people at their homes" (Khan, 2020, March 22). Then, he gives the reasons for how the people could detain themselves in self-quarantine and why. Through these reasons, he emphasis self-quarantine and define why people have to go for self-quarantine because the virus is being spread due to the social gathering, and we can save the country with the dangerous COVID 
19 if the people isolate themselves and avoid to attend the public gathering. All the comments as mentioned earlier clear that Khan uses persuasive strategies in a political context that persuades and helps in opinion formation, such as (Higgin \& Walker, 2012; Ting, 2018; Sibtain et al., 2020) argue that persuasive language is often helpful to get the attention of the people and impose their ideology on the mind of the people. Moreover, van Dijk (1997b) comments that the purpose of Discourse Analysis is to explore the relationships of determination and causality that function between discursive events, texts, and practices, as well as the relationships of determination and causality functions between broader cultural, political and social structures, processes and relations.

c) Pathos

Moreover, the third persuasive and rhetorical device that IK uses in his speeches is Pathos (Sibtain et al., 2020). According to Ting (2018), Higgin \& Walker (2012), and Sibtain et al. (2020), Pathos is a persuasive strategy used by Aristotle in his work to create the feeling of catharsis for the spectators. However, the study aims to point out the elements of Pathos in Khan's speeches, such as, in his speech on March 23, 2020, he uses this rhetorical device to persuade the minds of people through emotional words and these emotional words could also be found in other speeches of Premier of Pakistan Imran Khan. For example, he uses the emotional words like my Pakistanis, $25 \%$ poor people, I am thinking for the poor and needy people, be in selfquarantine, that is a trial from Allah, and I want to bring you in confidence, (Khan, 2020, March 22) there are stress and high tone to convince the people that they should accept and follow his ideology and agenda related to 
coronavirus. The hidden agenda in his speech could be understood only through social and political contexts. For instance, van Dijk (1997b) explains that "at the most general and abstract level, shared cultural values may be declared typical for political systems" (p. 16). He is also firm in sandwiching the emotions, as he starts with the words of appreciation and often ends with words of appreciation.

Furthermore, after this speech, IK proclaimed to lockdown the country and go-ahead to his next agenda of relaxation in debt and being granted aid by the IMF and World Bank through UNO. For instance, his live television address, he has appealed to the different financial and political world organizations and leaders for help for the poor people in developing countries. Such as, a news report on April 12, 2020, depicted that Imran Khan appealed to the world's heads of financial institutions, United Nations, and World leaders to "launch an initiative that will give debt relief to the developing countries to combat coronavirus (Gul, 2020)." During his address, Khan said that his appeal would be supportive for the solution of problems being faced by the developing countries, i.e., like the high debt-to-GDP ratio, which Pakistan is also facing nowadays. Moreover, Khan argues that his primary concern was that the poor people should not die of hunger due to the lockdown while containing the COVID-19 pandemic. Through his persuasive and strong language skills, he made UNO convince for debt relaxation and financial aid for his country, so he fulfills the food needs for his poor people. Therefore, PDA enables the researchers to point out the 
hidden agenda in political speeches through social and political context van Dijk (1997b).

\section{CONCLUSION}

A few outlined key points from the results of the analysis are that Premier Imran Khan has a firm grasp on stressing on the essential factors of communication. The ethical appeal is very well generated as we observe the intactness of all the cultural and societal ethics as well as religious ethics. The Pathos is very well connected as he understands the pain points and does enough to stress upon them. He is Logical about facts, numbers, certainty, and the precise nature of things. He portrays every event through the showcase of a timeline.

The data analysis, the researchers find that Imran Khan the leader of Pakistan has strong language skills that he uses to persuade the people, for instance, he, in his speeches related to COVID 19, creates the awareness for his nation about the causes, effects, symptoms, solutions, and the steps that have been taken by his Cabinet. He uses the language that the nation likes and feels that he is speaking their words for them. Moreover, he highlights the problems related to financial matters and suggests that people must follow precautions like hand-washing and self-isolation in order to keep themselves away from this virus because the state would not be able to bear the responsibility of food and other necessities due to the lack of funds. Then he urges the UNO for debt relaxation and funds for the help of their poor masses. Moreover, through PDA, we can understand the hidden agenda in Khan's speeches, especially by employing the model of PDA by van Dijk (1997b). 


\section{REFERENCES}

Dunmire, P. L. (2012), Political Discourse Analysis: Exploring the Language of Politics and the Politics of Language. Language and Linguistics Compass, 6, 735-751. https://doi.org/10.1002/lnc3.365

Fischer, F., \& Gottweis, H. (eds.). (2012). The argumentative turn revisited: Public policy as communicative practice. Durham, NC; Duke University Press.

Vulchanova, M., Vulchanov, V., Fritz, I. and Milburn, E. A. (2019). Language and perception: Introduction to the Special Issue "Speakers and Listeners in the Visual World". Journal of Cultural Cognitive Science, 3, 103-112 (2019). https://doi.org/10.1007/s41809-019$\underline{00047-\mathrm{Z}}$

Gul, A. (2020, April 12). Pakistan PM Seeks Debt Relief for Developing Nations to Fight Virus. VOA News. Retrieved from https://www.voanews.com/science-health/coronavirusoutbreak/pakistan-pm-seeks-debt-relief-developing-nations-fight$\underline{\text { virus }}$

Hani, C., Trieu, N.H., Saab, I., Dangeard, S., Bennani, S., Chassagnon, G. and Revel, M.-P. (2020). COVID-19 pneumonia: A review of typical CT findings and differential diagnosis. Diagnostic and Interventional Imaging, 101(5), 263-268. https://doi.org/10.1016/j.diii.2020.03.014 
Hassan, A. (2018). Language, Media, and Ideology: Critical Discourse Analysis of Pakistani News Bulletin Headlines and Its Impact on Viewers. SAGE. https://doi.org/10.1177/2158244018792612

Higgin, C. \& Walker, R. (2012). Ethos, Logos, Pathos: Strategies of Persuasion in Social/Environmental Reports. Accounting Forum, 36(3), 194-208. https://doi.org/10.1016/j.accfor.2012.02.003

Khan, I. [Duniya News]. (2020, March 17). PM Imran Khan Addresses to Nation on Coronavirus | March 172020 | Dunya News [Video file]. Retrieved from https://www.youtube.com/watch?v=NzCzJK_dkoE

Khan, I. [Public News]. (2020, March 22). PM Imran Khan addresses the nation | March 222020 [Video file]. Retrieved from https://www.youtube.com/watch?v=5A-mu01NdYk

Kirvalidze, N. and Samnidize, N. (2016). Political discourse as a Subject of Interdisciplinary Studies. Journal of Teaching and Education, 5(1), 161-170. Retrieved from http://universitypublications.net/jte/0501/pdf/DE5C282.pdf on May 03, 2020

Latif, E. A. (2016). Analysing Political Speeches: Rhetoric, Discourse and Metaphor. Metaphor and Symbol, 31(4), 250252. https://doi.org/10.1080/10926488.2016.1223462

Li, Q., Guan, X., Wu, P. et al. (2020). Early Transmission Dynamics in Wuhan, China, of Novel Coronavirus-Infected Pneumonia. The New England Journal of Medicine, 382(13), 1199-1207. DOI: $\underline{\text { 10.1056/NEJMoa2001316 }}$ 
Martin, J. N., \& Nakayama, T. K. (2010). Language and Intercultural Communication. Intercultural communication in contexts. New York, NY: McGraw- Hill.

Norali, N., \& Rezaei, S. (2016). Language and power: The use of persuasive techniques in Iran and U.S. President Speeches. Journal of Language Teaching $\quad$ 1203-1209. https://doi.org/10.17507/jltr.0706.19

Rogers, R., \& Schaenen, I. (2014). Critical Discourse Analysis in Literacy Education: A Review of the Literature. Reading Research Quarterly, 49(1), 121-143. Retrieved April 28, 2020, from www.jstor.org/stable/43497640

Sarfo, E. \& Krampa, A. E (2013). Language at War: A Critical Discourse Analysis of Speeches of Bush and Obama on Terrorism. International J. Soc. Sci. \& Education, 3(2), 378-390. Retrieved from http://ijsse.com/ on May 5, 2020

Shah, M. I. \& Noreen, A. (2018). A Critical Discourse Analysis of Prime Minister of Pakistan Imran Khan's First Public Address. Public Policy and Administration Research, 8(9), 1-6. Retrieved from https://www.iiste.org/Journals/ on May 8, 2020

Sharififar, M. \& Rahimi, E. (2015). Critical Discourse Analysis of Political Speeches: A Case Study of Obama's and Rouhani's Speeches at UN. Theory and Practice in Language Studies, 5(2), 343-349. http://dx.doi.org/10.17507/tpls.0502.14 
Sibtain, M., Aslam, M. Z., Khan, A., Khan, M., Atiq, M. \& Bhatti, H. (2020). Rhetorical and Persuasive Strategies Employed by Imran Khan in his Victory Speech: A Socio-Political Discourse Analysis. International Journal of English Linguistics, 10(2), 249-356. https://doi.org/10.5539/ijel.v10n2p349

Ting, S. (2018). Ethos, Logos and Pathos in University Students' Informal Requests. Gema Online Journal of Language Studies, 18(1), 234-251. http://doi.org/10.17576/gema-2018-1801-14

van Dijk, T. A. (1997b). What is political discourse analysis? In Blommaert, J. and Bulcaen, C. (eds) Political Linguistics, Amsterdam: Benjamins, $11-52$.

van Dijk, T. A. (2000). Ideology: A multidisciplinary approach. London: SAGE Publications Ltd. http://dx.doi.org/10.4135/9781446217856

van Dijk, T. A. (2005). Contextual knowledge management in discourse production. In Wodak, R. \& Chilton, P. A New Agenda in (Critical) Discourse Analysis: Theory, methodology and interdisciplinarity, 13, 71-100. https://doi.org/10.1075/dapsac.13.07dij

van Dijk, T. A. (2006). Discourse and manipulation. Discourse \& Society, 17(3), 359-383. https://doi.org/10.1177/0957926506060250

Wang, J. (2010). A critical discourse analysis of Barack Obama's speeches. Journal of Language Teaching and Research, 1(3), 254-261. DOI: $\underline{10.4304 / j 1 \mathrm{tr} .1 .3 .254-261}$

WMHC (2020). Wuhan Municipal Health and Health Commission's Briefing on the Current Pneumonia Epidemic Situation in Our City. Retrieved 
from http://wjw.wuhan.gov.cn/front/web/showDetail/2019123108989 on April 1, 2020.

Wodak, R. (2011). The discourse of politics in action: Politics as usual (2 $2^{\text {nd }}$ revised edition). London, UK: Palgrave.

World Health Organization (WHO) (2020). Coronavirus disease (COVID-19) Pandemic. $\quad$ Retrieved from https://www.who.int/emergencies/diseases/novel-coronavirus-2019 on May 25, 2020

World Health Organization (WHO) (2020a). Novel Coronavirus - China: Confirmed Cases Over Time. Retrieved from https://covid19.who.int/region/wpro/country/cn on May 10, 2020.

World Health Organization (WHO) (2020b). Coronavirus disease (COVID-19) advice for the public. Retrieved from https://www.who.int/emergencies/diseases/novel-coronavirus2019/advice-for-public on May 10, 2020

Wu, F., Zhao, S., Yu, B. et al. (2020). A new coronavirus associated with human respiratory disease in China. Nature 579, 265-269. https://doi.org/10.1038/s41586-020-2008-3

Xie, Q. (2018). Critical Discourse Analysis of News Discourse. Theory and Practice in Language Studies, 8(4), 399-403. DOI: http://dx.doi.org/10.17507/tpls.0804.06 